\title{
Grazing Method Effect on Topographical Vegetation Characteristics and Livestock Performance in the Nebraska Sandhills
}

\author{
Mitchell B. Stephenson, ${ }^{1}$ Walter H. Schacht, ${ }^{2}$ Jerry D. Volesky, ${ }^{3}$ Kent M. Eskridge, ${ }^{4}$ Eric M. Mousel, ${ }^{5}$ \\ and Dennis Bauer ${ }^{6}$
}

\begin{abstract}
Authors are ${ }^{1}$ Graduate Research Assistant, Department of Animal and Range Science, New Mexico State University, Las Cruces, NM 88003, USA; ${ }^{2}$ Professor, Agronomy and Horticulture Department, University of Nebraska-Lincoln, Lincoln, NE 68583, USA; ${ }^{3}$ Professor, University of NebraskaLincoln, West Central Research and Extension Center, North Platte, NE 69101, USA; ${ }^{4}$ Professor, Department of Statistics, University of NebraskaLincoln, Lincoln, NE 68583, USA; ${ }^{5}$ Extension Cow-Calf Educator, University of Minnesota Cooperative Extension Service, North Central Research and Outreach Center, Grand Rapids, MN 55744, USA; and ${ }^{6}$ Extension Educator, University of Nebraska-Lincoln, Ainsworth, NE 69210, USA.
\end{abstract}

\begin{abstract}
A study was conducted on upland range in the Nebraska Sandhills to determine differences in plant species frequency of occurrence and standing crop at various topographic positions on pastures grazed with short-duration grazing (SDG) and deferred-rotation grazing (DRG). Pastures within each grazing treatment were grazed at comparable stocking rates $(S D G=1.84$ animal unit months (AUM) $\cdot \mathrm{ha}^{-1} ; \mathrm{DRG}=1.94 \mathrm{AUM} \cdot \mathrm{ha}^{-1}$ ) by cow-calf pairs from 1999 to 2005 and cow-calf pairs and spayed heifers from 2006 to 2008. Plant frequency of occurrence data were collected from permanently marked transects prior to, midway through, and at the conclusion of the study (1998, 2003, and 2008, respectively) and standing crop data were collected annually from 2001 to 2008 at four topographic positions (dune top, interdune, north slope, and south slope). Livestock performance data were collected during the last $3 \mathrm{yr}$ of the study (2006 to 2008). Positive change in frequency of occurrence of prairie sandreed (Calamovilfa longifolia [Hook.] Scribn.) was $42 \%$ greater on DRG pastures than SDG after 10 yr. Total live standing crop did not differ between DRG and SDG except in 2001 when standing crop was $23 \%$ greater on DRG pastures. Standing crop of forbs and sedge was variable between grazing methods on interdune topographic positions depending on year. Average daily gain of spayed heifers $\left(0.84 \pm 0.05 \mathrm{~kg} \cdot \mathrm{d}^{-1} \mathrm{SE}\right)$ did not differ between SDG and DRG. Overall, SDG was not superior to a less intensively managed grazing method (i.e., DRG) in terms of vegetation characteristics and livestock performance.
\end{abstract}

Key Words: deferred rotation, interdunes, short-duration grazing, topography, vegetation change

\section{INTRODUCTION}

Range scientists have studied short-duration grazing (SDG) on many grazing lands to quantify its value to rangeland vegetation and livestock performance (Hart et al. 1988; White et al. 1991; Taylor et al. 1993; Manley et al. 1997; McCollum et al. 1999; Derner and Hart 2007) since Allan Savory reported on it in the 1970s. Early reports on SDG (Savory and Parsons 1980; Savory 1983; Savory 1999) claimed increased carrying capacity while increasing or maintaining desirable plant species composition, standing crop, and livestock performance. SDG also has been reported to increase the use and efficiency of the available forage resource by increasing livestock stocking density and improving distribution and uniformity of grazing through additional fencing and watering points (Heitschmidt and Walker 1983; Scott et al. 1993). A majority of research conducted over the last $30 \mathrm{yr}$, however, has concluded that

Research was a contribution of the University of Nebraska Agricultural Research Division, supported in part by funds provided through the Hatch Act and the University of Nebraska Foundation.

Correspondence: Mitchell B. Stephenson, New Mexico State University, Dept of Animal and Range Science, Box 30003 MSC 3-1, Las Cruces, NM 88003, USA. Email: mitchs@nmsu.edu

Manuscript received 17 January 2013; manuscript accepted 24 June 2013.

(c) 2013 The Society for Range Management
SDG has little, if any, benefit to livestock performance or vegetation characteristics on upland ranges when compared to other grazing methods (Holechek et al. 2000; Briske et al. 2008; Briske et al. 2011).

Deferred-rotation grazing (DRG) is another common rotational grazing method that has been researched and frequently used on rangelands in the United States and Australia (Sampson 1951; Owensby et al. 1973; Hart et al. 1988; Manley et al. 1997; Ash et al. 2011). DRG and SDG differ primarily in the number of pastures and the number of grazing periods that occur during the growing season. DRG generally has fewer pastures (two to five pastures) than SDG (eight pastures or more) and only a single grazing period for each pasture during the growing season. Grazing within DRG pastures is usually rotated annually so that different pastures are deferred until plants reach reproductive maturity in each year. In contrast, grazing within SDG pastures is characterized by several short grazing periods followed by periods of rest throughout the growing season. Studies on northern mixed-grass prairie in southeastern Wyoming found little difference in regard to herbage production, basal cover of desirable grass species, or livestock performance on pastures grazed with DRG (three herds and four pastures), SDG (one herd and eight pastures), and continuous grazing after 6 yr (Hart et al. 1988) and 13 yr (Manley et al. 1997). However, a major remaining question pertains to how plant species composition and herbage production respond to SDG 
and DRG with the potential interacting effect of topographic position.

Topography of grazing lands is a factor that affects vegetation characteristics and livestock behavior and performance. Topographic position (e.g., ridge top or lowlands) influences botanical composition, soil moisture holding capacity, soil texture, evaporation rates, and soil-surface temperatures in the Nebraska Sandhills (Tolstead 1942; Barnes and Harrison 1982; Barnes et al. 1984; Schacht et al. 2000). Topographic position also influences livestock grazing behavior, with cattle generally utilizing lowlands in greater proportion than other topographic positions (i.e., slopes and ridges; Senft et al. 1985; Milchunas et al. 1989). Because of differences in plant species distribution and the influence on livestock utilization patterns, topographic position may influence vegetation characteristics differently based on grazing strategies. As a result, topographic position should be included as a factor within grazing studies conducted in topographically diverse pastures (Milchunas et al. 1989).

The objectives of this study were to 1) determine differences in frequency of occurrence of plant species, standing crop, and livestock performance between SDG with eight pastures and DRG with four pastures and 2) evaluate the effect of grazing method and topographic position on plant community changes and standing crop in the Nebraska Sandhills. Reports from managers and advisors using SDG in the Nebraska Sandhills and surrounding grazing lands (Barnhart et al. 1998; Gerrish and Roberts 1999) were the basis of a hypothesis expecting greater high-succession plant species frequency, forage production, and livestock performance with SDG compared to DRG over a longer term $(10 \mathrm{yr})$ in the transition between semiarid and subhumid climatic zones. We also hypothesized that temporal changes in frequency of occurrence and standing crop of topographic positions favored by grazing cattle (i.e., lowlands) would be less pronounced after $10 \mathrm{yr}$ on SDG pastures than on DRG pastures because repeated defoliation of favored forage plants during a grazing period would be minimized with short grazing periods and there would be opportunity for forage species to recover from defoliation between grazing periods.

\section{MATERIALS AND METHODS}

\section{Study Site}

Research was conducted at the University of Nebraska-Lincoln Barta Brothers Ranch in the eastern Nebraska Sandhills (lat $42^{\circ} 13^{\prime} 32^{\prime \prime} \mathrm{N}$, long $99^{\circ} 38^{\prime} 09^{\prime \prime} \mathrm{W}$; elevation=765 m). Climate is typical of a midcontinental prairie region located within the transition zone between semiarid and subhumid climates. January temperatures average $-6.8^{\circ} \mathrm{C}$ and July temperatures average $22.5^{\circ} \mathrm{C}$. The long-term average annual precipitation is $576 \pm 20 \mathrm{~mm}$ SE with approximately $76 \%$ of the annual precipitation occurring from April through September (High Plains Regional Climate Center 2012).

Ninety percent of the study area was classified as upland range and the remaining $10 \%$ as intermixed, subirrigated meadows and wetlands (Schacht et al. 2000). Uplands were characterized by grass-covered sand dunes oriented west by northwest to east by southeast. Topography of the study area consists of $15 \%$ dune tops, $15 \%$ interdune, $34 \%$ north-facing slopes, and 36\% south-facing slopes (M. Stephenson, unpublished data, 2010) with dune heights up to $40 \mathrm{~m}$ from adjacent valley floors (Schacht et al. 2000). Study pastures are comprised mostly of sands ecological sites with scattered sandy and choppy sands ecological sites. Soils are in the Valentine series (mixed, mesic Typic Ustipsamments).

Vegetation within the study area is a mixture of warm- and cool-season grasses, sedges, forbs, and shrubs. Common grasses include prairie sandreed (Calamovilfa longifolia [Hook] Scribn.), sand bluestem (Andropogon hallii Hack), little bluestem (Schizachyrium scoparium [Michx.]), switchgrass (Panicum virgatum L.), blue grama (Bouteloua gracilis [Willd. ex Kunth] Lag. ex Giffiths), prairie junegrass (Koeleria macrantha [Ledeb.] J. A. Schultes), needlegrasses (Hesperostipa comata Trin. \& Rupr. and Hesperostipa spartea Trin.), and bluegrass species (Poa compressa L. and Poa pratensis L.). Several species of sedges (Carex spp.) also are common. Common forbs and shrubs include western ragweed (Ambrosia psilostachya DC.), cudweed sagewort (Artemisia ludoviciana Nutt.), and leadplant (Amorpha canescens Nutt.; Kaul et al. 2006). Topographic position and aspect of dunes in the Sandhills affects plant distribution with warm-season tallgrasses such as prairie sandreed and sand bluestem and the forb western ragweed being more associated with south slopes and little bluestem, cool-season grasses such as needlegrasses and prairie junegrass, and the shrub leadplant being associated with north slopes. Plants associated with interdune positions include bluegrasses, switchgrass, and cudweed sagewort (Schacht et al. 2000).

\section{Grazing Treatments}

Implementation of grazing treatments began in 1999 and continued through 2008. Prior to the study, pastures were continuously grazed during the 5-mo grazing season (15 May to 15 October) since the mid-1950s by cow-calf pairs at moderate stocking rates (about 1.8 animal unit months $\left.[\mathrm{AUM}] \cdot \mathrm{ha}^{-1}\right)$. At the initiation of the study, range condition was classified as good to excellent by the US Department of Agriculture Natural Resources Conservation Service (Schacht et al. 2000).

A total of 1281 ha were divided to create two replications of an eight-pasture SDG treatment and a four-pasture DRG treatment (Table 1). Pastures within the SDG and DRG treatments were grazed by Angus and Angus-cross cow-calf pairs from 1999 through 2005 and by cow-calf pairs and spayed heifers from 2006 through 2008. The grazing season for the study ran from approximately 15 May to 15 October except in 2002 and 2006 when cattle were removed on 15 September and 30 September, respectively, because of drought conditions. Remaining herbage visual obstruction was estimated using a Robel pole (Robel et al. 1970) by the authors in late October each year. A visual obstruction height of 7-10 $\mathrm{cm}$ represented $50-60 \%$ use. When mean visual obstruction was less than 7-10 cm for a pasture, subsequent-year stocking rate was reduced by $5-10 \%$. Conversely, stocking rate was increased in pastures with above-average visual obstruction to equalize utilization across all treatment pastures. Mean annual stocking rate was comparable between SDG and 
Table 1. Pasture size, cattle numbers, stocking rate, and stocking density (mean $\pm \mathrm{SE}$ ) on replications of an eight-pasture short-duration grazing treatment and a four-pasture deferred-rotation grazing treatment from 1999 through 2008 at the Barta Brothers Ranch in the northeastern Nebraska Sandhills.

\begin{tabular}{|c|c|c|c|c|}
\hline & \multicolumn{2}{|c|}{$\mathrm{SDG}^{1}$} & \multicolumn{2}{|c|}{ DRG } \\
\hline & Replication 1 & Replication 2 & Replication 1 & Replication 2 \\
\hline Mean pasture size (ha) & $65 \pm 4$ & $51 \pm 2$ & $44 \pm 2$ & $40 \pm 1$ \\
\hline Mean annual number of cow-calf pairs: $1999-2005$ & $137 \pm 9$ & $101 \pm 1$ & $47 \pm 1$ & $43 \pm 1$ \\
\hline Mean annual number of cow-calf pairs: 2006-2008 & $127 \pm 0$ & $90 \pm 0$ & $37 \pm 0$ & $33 \pm 0$ \\
\hline Mean annual number of spayed heifers: 2006-2008 & $18 \pm 2$ & $18 \pm 2$ & $18 \pm 1$ & $18 \pm 2$ \\
\hline Mean stocking rate: 1999-2008 (AUM · ha-1) & $1.90 \pm 0.09$ & $1.78 \pm 0.04$ & $1.95 \pm 0.05$ & $1.93 \pm 0.05$ \\
\hline Mean stocking density: $1999-2008^{2}\left(\mathrm{AU}^{-\mathrm{ha}^{-1}}\right)$ & $3.28 \pm 0.14$ & $3.09 \pm 0.04$ & $1.66 \pm 0.03$ & $1.64 \pm 0.03$ \\
\hline
\end{tabular}

${ }^{1} \mathrm{SDG}$ indicates short-duration grazing; DRG, deferred-rotation grazing; AUM, animal unit month; and AU, animal unit.

${ }^{2} \mathrm{Cow}$-calf pairs $=1.5 \mathrm{AU}$, heifers $=0.70 \mathrm{AU}$, and bulls $=2.0 \mathrm{AU}$.

DRG treatments, $1.84 \mathrm{AUM} \cdot \mathrm{ha}^{-1}$ and $1.94 \mathrm{AUM} \cdot \mathrm{ha}^{-1}$, respectively (Table 1$)$. The slightly lower stocking rate on SDG pastures was the result of miscalculations in initial sizes of two pastures that were corrected after year 1 and small decreases in stocking rate on some SDG pastures following year-end evaluations. Stocking density was approximately two times greater on SDG pastures than on DRG pastures, 3.19 $\mathrm{AU} \cdot \mathrm{ha}^{-1}$ and $1.65 \mathrm{AU} \cdot \mathrm{ha}^{-1}$, respectively (Table 1 ).

Cow-calf pairs and spayed heifers on the SDG replications were rotated through eight pastures three times (cycles) per grazing season. Timing of grazing was based on the practice of moving cattle rapidly through pastures early in the growing season and increasing the grazing period length as forage matured. The first grazing cycle (mid-May to early June, $16 \mathrm{~d}$ ) had 2-d grazing periods within each pasture. The second (early June to late July, $\sim 56 \mathrm{~d}$ ) and third (late July to midOctober, $\sim 80 \mathrm{~d}$ ) cycles had grazing periods averaging $6 \mathrm{~d}$ or 7 $\mathrm{d}$ and $10 \mathrm{~d}$ or $11 \mathrm{~d}$, respectively (Fig. 1). Exact length of grazing periods in the second and third cycles varied because of individual pasture size and flexibility in management based on observations of growing conditions and forage availability. Annual sequence of grazing on pastures was rotated by using an $8 \times 8$ Williams (1949) design with two added years. This design is a Latin-square type of repeated measures design that balances out time of grazing over pasture and year in such a

\begin{tabular}{|c|c|c|c|c|c|c|}
\hline Stage & May & June & July & August & September & October \\
\hline $\mathrm{s}$ & & & & & & \\
\hline $\mathrm{T}$ & & & & & & \\
\hline$U$ & & & & & & \\
\hline $\mathrm{V}$ & & & & & & \\
\hline W & & & & & & \\
\hline$x$ & & & & & & \\
\hline $\mathrm{Y}$ & & & & & & \\
\hline Z & 2 Days 2 & 6 or 7 & र & & or 11 Days & \\
\hline
\end{tabular}

B) DRG

\begin{tabular}{|c|c|c|c|c|c|c|}
\hline Stage & May & June & Ju & August & September & October \\
\hline A & \multicolumn{2}{|c|}{\begin{tabular}{|l|l|}
31 Days & \\
\end{tabular}} & & & & \\
\hline$B$ & & & 6 Days & & & \\
\hline $\mathrm{C}$ & & & & 41 Days & & \\
\hline $\mathrm{D}$ & & & & & 45 Day & \\
\hline
\end{tabular}

Figure 1. Time of grazing and number of days cattle grazed on pastures within $A$, eight-pasture short-duration grazing (SDG) treatment replications and $B$, four-pasture deferred-rotation grazing (DRG) treatment replications. Time of grazing was rotated annually within pastures of both treatments. way to remove year and pasture effects for each grazing treatment replication.

Cow-calf pairs and spayed heifers on the DRG replications were rotated through four pastures once during the growing season. Each pasture was grazed approximately 31-45 d depending on when grazing occurred in relation to the growing season (Fig. 1). Length of grazing periods within pastures increased as the growing season progressed. Annual sequence of grazing was rotated by repeating two $4 \times 4$ Williams (1949) designs with two added years.

\section{Change in Frequency of Occurrence}

Baseline frequency of occurrence data were collected during the summer of 1998 from 87 sites with four permanently marked transects per site, one at each topographic position (i.e., dune top, interdune, north slope, and south slope). Dunes were not evenly distributed over the landscape, but an effort was made to locate sampling sites with a spacing of approximately one site per 15 ha. In 2003 and 2008, frequency of occurrence data were again collected at 77 of the sites. Some of the originally marked sites and transects were abandoned because of flooding in 1998 and early 1999 and others could not be found in 2003 . Only data collected from sites and transects in all years (1998, 2003, and 2008) were used within the analysis.

Transects at each site ran parallel with the contour of the land on dune tops, at the midpoint between dune tops and valleys for the north- and south-facing slopes, and through the center of interdunal valleys. Transects on slopes and dune tops were $100 \mathrm{~m}$ long. Transects on smaller interdune positions were $50 \mathrm{~m}$ long. Frequency of occurrence data were collected using a square $0.1-\mathrm{m}^{2}$ quadrat placed at $4-\mathrm{m}$ intervals along each transect. The 4-m interval was selected after developing a species-area curve relating interval to number of species (Mueller-Dombois and Ellenberg 1974). The $0.1-\mathrm{m}^{2}$ quadrat size was selected because it was the largest size that resulted in a frequency of occurrence less than $100 \%$ for each species encountered in the sampling process (Daubenmire 1968). Frequency of occurrence of all rooted plant species was recorded at each quadrat placement.

\section{Standing Crop}

Cumulative effect of grazing treatment on aboveground standing crop was determined by harvesting standing crop 
annually in mid-August beginning in 2001. The mid-August harvest was selected to correspond with the approximate time of peak herbage yield. Two pastures within each DRG and SDG replication were selected for standing crop data collection. Three sites from 2001 through 2008 within the two pastures were selected and five exclosures $(1.2 \times 1.2 \mathrm{~m}$ wire panels) were placed along a transect line at each topographic position. The design resulted in a total of 240 exclosures (2 grazing treatments $\times 2$ replications $\times 3$ sites $\times 4$ topographic positions $\times 5$ exclosures). Exclosures were moved at the beginning of each year to capture the effect of the previous year's grazing treatment. Standing crop was estimated by hand-clipping all standing herbaceous vegetation at ground level within a 0.25 $\mathrm{m}^{2}(0.25 \times 1.0 \mathrm{~m})$ quadrat placed within the exclosure. All herbaceous material was separated into functional groups consisting of warm-season grasses, cool-season grasses, sedges, or forbs. Current year's growth of shrubs (i.e., leaves and new stem tissue) also was collected from plants rooted within the quadrats. Standing dead plant material and litter were collected from 2004 to 2008. All separated plant material was placed in paper bags, oven-dried $\left(60^{\circ} \mathrm{C}\right)$ to a constant weight, and weighed.

\section{Livestock Performance}

In the last $3 \mathrm{yr}$ of the study (2006 through 2008), 15 to 20 Angus and Angus-cross, yearling, spayed heifers replaced 7 to 10 cow-calf pairs in each replication to determine grazing treatment effect on cattle weight gain. Cow-calf pair weights were estimated to range between $635 \mathrm{~kg}$ and $726 \mathrm{~kg}$ and were considered a 1.5 animal unit equivalent (AUE). Average weight of the heifers during the grazing season was $308 \pm 3.8 \mathrm{~kg}$ SE with an AUE of 0.70. Heifers were moved onto pastures with the cow-calf pairs, but were removed 1-4 wk earlier for marketing purposes. Length of grazing season for heifers was $129 \mathrm{~d}$ in 2006, $126 \mathrm{~d}$ in 2007, and $121 \mathrm{~d}$ in 2008. In all years, heifers received a Synovex H implant and were weighed at the beginning and end of the grazing season following an overnight shrink.

\section{Statistical Analysis}

Differences in frequency of occurrence of plant species on DRG and SDG pastures were analyzed by evaluating the change in frequency of occurrence of plant species during the first 5-yr period (1999 to 2003) and over the total $10 \mathrm{yr}$ of the study (1999 to 2008). Changes in frequency of occurrence and standing crop data were analyzed using a mixed model analysis of variance (ANOVA) within SAS 9.3 (SAS Institute Inc., Cary, NC) that combined the DRG and SDG modified Williams' designs. Main effects for change in frequency of occurrence were grazing treatment and topographic position. Main effects evaluated for standing crop were grazing treatment, year, and topographic position. Year and topographic position were criss-crossed within the analysis resulting in a random effect of pasture within each grazing treatment. Livestock performance data were analyzed using a mixed model ANOVA with year and grazing treatment as main effects.

Two separate analyses were conducted with change in frequency and standing crop data to make comparisons at 1) the pasture level (i.e., grazing treatment) and 2) the finer scale of topographic position (i.e., topographic position and interactions). To assess the effect of grazing treatment at a pasture level, standing crop (e.g., total standing crop and warm-season grass standing crop) and change in frequency of occurrence (e.g., prairie sandreed) were weighted by the composition of each topographic position (i.e., $15 \%$ dune top, etc.) within experimental pastures. For comparisons at topographic position, analysis of data was conducted using the unweighted actual standing crop and change in frequency means to assess interactions of topographic position with grazing treatment and year. Because of relatively high variability of vegetation characteristics between treatment pastures, main effects and interactions were analyzed at an alpha level of 0.1 to determine significant differences.

\section{RESULTS}

\section{Precipitation Data}

Mean annual precipitation during the study period $(518 \mathrm{~mm})$ was below the long-term average $(576 \mathrm{~mm})$, especially during the first $5 \mathrm{yr}$ of the study (Fig. 2). Mean annual precipitation during the first 5 -yr period of the study (454 $\mathrm{mm}$; 1999 to 2003 ) was $21 \%$ below the long-term average, whereas mean precipitation during the second 5 -yr period (582 mm; 2004 to 2008) was near the average. Growingseason precipitation (April through September) was 21\% below the long-term average during the first 5 -yr period ( 352 $\mathrm{mm} ; 1999$ to 2003) and 7\% below during the second 5-yr period (417 mm; 2004 to 2008) (Fig. 2). Annual precipitation during the driest years, 1999 and 2002, was $28 \%$ and $42 \%$ below the average, respectively. Precipitation in the wettest year, 2008 , was $24 \%$ above the average.

\section{Change in Frequency of Occurrence}

Warm-Season Grasses. Frequency of all warm-season grass species included in the analysis either increased or remained relatively constant at $5 \mathrm{yr}$ and $10 \mathrm{yr}$ after the implementation of DRG and SDG treatments. Change in frequency of occurrence only differed between DRG and SDG treatments with prairie sandreed after $10 \mathrm{yr}$ at the pasture level and little bluestem with a grazing treatment-by-topographic position interaction (Table 2). From 1998 to 2008, frequency of prairie sandreed increased from $14.8 \pm 3.0 \%$ SE to $36.7 \pm 3.3 \%$ SE on DRG pastures and $17.6 \pm 1.5 \%$ SE to $33.2 \pm 2.5 \%$ SE on SDG pastures. This change in frequency of prairie sandreed over the $10 \mathrm{yr}$ of the study was $42 \%$ greater on DRG pastures than on SDG pastures (Table 2).

Little bluestem change in frequency exhibited a grazing treatment-by-topographic position interaction after both $5 \mathrm{yr}$ and 10 yr. From 1998 to 2003, change in frequency of little bluestem on south slopes decreased $(P \leq 0.05)$ by 8.7 percentage points on DRG pastures but increased on SDG pastures by 2.8 percentage points (Table 3 ). After $10 \mathrm{yr}$, there was no change in frequency difference between SDG and DRG on south slopes, but change in frequency of little bluestem differed between grazing treatments $(P \leq 0.05)$ on interdunes. Change in frequency on interdunes increased 


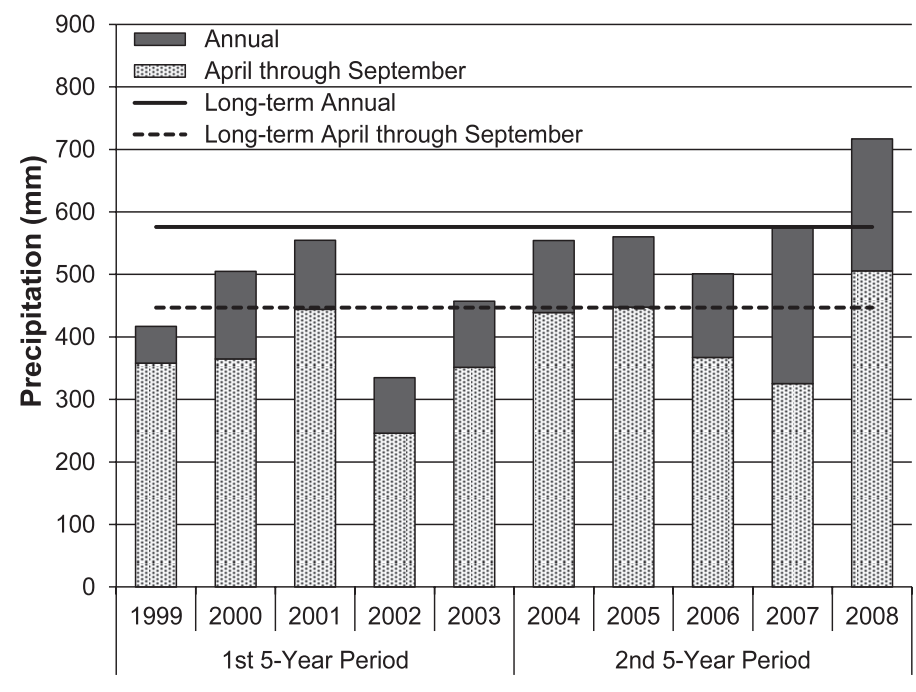

Figure 2. April through September and annual precipitation $(\mathrm{mm})$ recorded at the Barta Brothers Ranch from 1999 to 2008 and the long-term average April through September and annual precipitation (1961-2000) (High Plain Regional Climate Center 2012).

significantly more on DRG pastures than on SDG pastures where frequency of occurrence decreased (Table 3).

Cool-Season Graminoids. Grazing treatment influenced the change in frequency of needlegrasses during the first $5 \mathrm{yr}$ of the study at the pasture level (Table 2). Increase in frequency of occurrence of needlegrasses on SDG pastures from 1998 to $2003(30.1 \pm 4.3 \%$ SE to $48.5 \pm 3.9 \%$ SE) was nearly double the increase in frequency on DRG pastures $(49.4 \pm 1.6 \%$ SE to $58.8 \pm 3.7 \%$ SE) (Table 2). After $10 \mathrm{yr}$, though, change in frequency was similar for needlegrasses on DRG and SDG pastures. There was no grazing treatment or grazing treatment- by-topographic position interaction with any other cool-season graminoids after $5 \mathrm{yr}$ or $10 \mathrm{yr}$.

Forbs and Shrubs. Western ragweed frequency of occurrence decreased with both grazing treatments during the first $5 \mathrm{yr}$ and after $10 \mathrm{yr}$ (Table 2). During the first $5 \mathrm{yr}$, from 1998 to 2003, the decrease in western ragweed frequency of occurrence was 2.5 times greater on DRG pastures $(79.9 \pm 2.9 \%$ SE to $54.0 \pm 6.4 \% \mathrm{SE})$ than on SDG pastures $(72.6 \pm 2.0 \%$ SE to $62.3 \pm 3.2 \%$ SE) at the pasture level (Table 2). However, after $10 \mathrm{yr}$, change in frequency of western ragweed did not differ between grazing treatments. Change in frequency of other forbs and shrubs was not different between grazing treatments after $5 \mathrm{yr}$ or at the conclusion of the 10 -yr study.

\section{Standing Crop}

At the pasture level, a grazing treatment-by-year interaction was observed for total live standing crop $(P=0.04)$. However, differences between grazing treatments were found in only $1 \mathrm{yr}$ (Fig. 3). Total live standing crop was 23\% greater on DRG pastures than on SDG pastures in 2001. There were no total live standing crop differences between grazing treatments in other years. No differences were detected between SDG and DRG grazing treatments for standing crop of warm- or cool-season grasses, current year's growth of shrubs, or standing dead at the pasture level or at different topographic positions.

Grazing treatment interactions were found with standing crop of forbs $(P<0.01)$ and sedges $(P<0.01)$. Both functional groups had significant grazing treatment-bytopographic position-by-year interactions. Forb and sedge standing crop was variable at all topographic positions but most of the differences between grazing treatments were within the interdune topographic position. Forb standing

Table 2. Change in frequency of occurrence (mean $\pm \mathrm{SE}$ ) of plant species on eastern Nebraska Sandhills range grazed with deferred-rotation grazing and short-duration grazing from 1998 to 2008 and $P$-values for main effects of grazing method and topography and the interaction between these effects.

\begin{tabular}{|c|c|c|c|c|c|c|c|c|c|c|}
\hline & \multicolumn{5}{|c|}{ 5-yr change (1998-2003) } & \multicolumn{5}{|c|}{ 10-yr change (1998-2008) } \\
\hline & $\mathrm{DRG}^{1}$ & SDG & M & $\mathrm{T}$ & $M \times T$ & DRG & SDG & M & $\mathrm{T}$ & $M \times T$ \\
\hline & \multicolumn{2}{|c|}{------ percentage points ------- } & \multicolumn{3}{|c|}{------------P value ------------ } & \multicolumn{2}{|c|}{------- percentage points ------- } & \multicolumn{3}{|c|}{-----------P value----------- } \\
\hline \multicolumn{11}{|l|}{ Warm-season grasses } \\
\hline Prairie sandreed & $13.4 \pm 3.4$ & $6.5 \pm 2.9$ & 0.14 & 0.10 & 0.30 & $22.0 \pm 2.7$ & $15.5 \pm 2.3$ & 0.09 & $\leq 0.01$ & 0.66 \\
\hline Sand bluestem & $7.1 \pm 2.6$ & $1.4 \pm 2.2$ & 0.11 & 0.63 & 0.62 & $12.0 \pm 2.9$ & $7.7 \pm 2.4$ & 0.26 & $\leq 0.01$ & 0.61 \\
\hline Little bluestem & $2.8 \pm 3.4$ & $3.7 \pm 2.9$ & 0.83 & $\leq 0.01$ & $\leq 0.01$ & $3.1 \pm 3.5$ & $0.4 \pm 3.0$ & 0.57 & $\leq 0.01$ & 0.02 \\
\hline Switchgrass & $1.5 \pm 3.1$ & $5.5 \pm 2.6$ & 0.34 & $\leq 0.01$ & 0.42 & $5.2 \pm 3.7$ & $6.2 \pm 3.1$ & 0.84 & 0.041 & 0.15 \\
\hline Blue grama & $8.1 \pm 2.3$ & $6.6 \pm 2.0$ & 0.61 & $\leq 0.01$ & 0.99 & $9.4 \pm 3.1$ & $10.5 \pm 2.7$ & 0.79 & $\leq 0.01$ & 0.93 \\
\hline \multicolumn{11}{|l|}{ Cool-season graminoids } \\
\hline Prairie junegrass & $3.4 \pm 4.6$ & $-1.0 \pm 3.9$ & 0.48 & 0.10 & 0.55 & $6.0 \pm 4.1$ & $3.7 \pm 3.5$ & 0.67 & 0.34 & 0.27 \\
\hline Needlegrasses & $9.4 \pm 3.8$ & $18.4 \pm 3.2$ & 0.09 & 0.33 & 0.34 & $4.3 \pm 3.6$ & $11.8 \pm 3.1$ & 0.14 & 0.94 & 0.90 \\
\hline Bluegrasses & $-2.6 \pm 2.9$ & $-2.4 \pm 2.5$ & 0.95 & $\leq 0.01$ & 0.99 & $8.7 \pm 4.0$ & $8.0 \pm 3.5$ & 0.89 & $\leq 0.01$ & 0.98 \\
\hline Sedge & $-17.4 \pm 3.3$ & $-17.0 \pm 2.8$ & 0.92 & 0.02 & 0.72 & $-4.1 \pm 3.1$ & $-1.0 \pm 2.7$ & 0.46 & $\leq 0.01$ & 0.17 \\
\hline \multicolumn{11}{|l|}{ Forbs and Shrubs } \\
\hline Western ragweed & $-25.9 \pm 5.2$ & $-10.3 \pm 4.4$ & 0.03 & 0.25 & 0.76 & $-14.4 \pm 7.2$ & $-20.9 \pm 6.2$ & 0.50 & 0.19 & 0.97 \\
\hline Cudweed sagewort & $5.1 \pm 1.1$ & $4.8 \pm 1.0$ & 0.87 & $\leq 0.01$ & 0.97 & $7.1 \pm 1.8$ & $8.2 \pm 1.5$ & 0.65 & $\leq 0.01$ & 0.47 \\
\hline Leadplant & $2.6 \pm 1.1$ & $2.1 \pm 1.0$ & 0.75 & 0.44 & 0.39 & $2.0 \pm 1.3$ & $0.8 \pm 1.1$ & 0.49 & 0.08 & 0.29 \\
\hline
\end{tabular}

${ }^{1} \mathrm{DRG}$ indicates deferred-rotation grazing; SDG, short-duration grazing; M, grazing method; and T, topography. 
Table 3. Frequency of occurrence (mean \pm SE) of little bluestem on deferred-rotation grazing and short-duration grazing pastures in 1998, 2003, and 2008 and the change in frequency of occurrence from 1998 to 2003 (5-yr change) and 1998 to 2008 (10-yr change) at dune top, interdune, north slope, and south slope topographic positions.

\begin{tabular}{|c|c|c|c|c|c|c|}
\hline Topographic position & Grazing method & 1998 & 2003 & 2008 & 5-yr change & 10-yr change \\
\hline & & \multicolumn{3}{|c|}{ 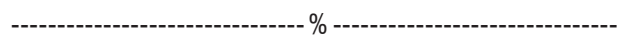 } & \multicolumn{2}{|c|}{-----------percentage points----------- } \\
\hline $\mathrm{DT}^{1}$ & $\mathrm{DRG}$ & $39.4 \pm 5.4$ & $36.5 \pm 4.9$ & $35.0 \pm 6.2$ & $-2.9 \pm 4.3$ & $-4.4 \pm 4.7$ \\
\hline \multirow[t]{2}{*}{ ID } & DRG & $2.1 \pm 1.1$ & $6.4 \pm 2.4$ & $9.5 \pm 4.0$ & $4.4 \pm 4.3$ & $7.4 \pm 4.7^{*}$ \\
\hline & SDG & $9.6 \pm 5.0$ & $7.4 \pm 2.1$ & $4.2 \pm 1.3$ & $-2.2 \pm 3.7$ & $-5.3 \pm 4.0$ \\
\hline NS & DRG & $32.0 \pm 6.2$ & $48.4 \pm 4.4$ & $47.1 \pm 3.8$ & $16.3 \pm 4.3$ & $15.1 \pm 4.7$ \\
\hline SS & DRG & $30.9 \pm 5.5$ & $22.2 \pm 4.7$ & $23.6 \pm 3.8$ & $-8.7 \pm 4.3^{*}$ & $-7.3 \pm 4.7$ \\
\hline & SDG & $31.9 \pm 4.8$ & $34.7 \pm 5.6$ & $28.8 \pm 4.2$ & $2.8 \pm 3.7$ & $-3.1 \pm 4.0$ \\
\hline
\end{tabular}

${ }^{1}$ DT indicates dune top; DRG, deferred-rotation grazing; SDG, short-duration grazing; ID, interdune; NS, north slope; and SS, south slope.

*Indicates differences between grazing treatments at the same topographic position $(P \leq 0.05)$.

crop on interdunes was greater on DRG pastures than on SDG pastures in 2001, 2007, and 2008 (Fig. 4A). In contrast, SDG pastures had greater amounts of forb standing crop in 2003, 2004, and 2005. Sedge standing crop on interdunes was greater on DRG pastures than on SDG pastures in 2002 and 2003, but there were no differences in other years of the study (Fig. 4B).

Significant topographic position-by-year interactions were observed for total live standing crop $(P<0.01)$ and coolseason grasses $(P<0.01)$. Total live standing crop was greater on interdunes compared to other topographic positions in all years except 2002, 2004, and 2006 (Fig. $5 \mathrm{~A})$. The driest year of the study was 2002, and 2006 was characterized by severe drought early in the growing season. Interdunes produced greater amounts of cool-season grass standing crop compared to other topographic positions in 2001, 2005, and 2008 (Fig. 5B).

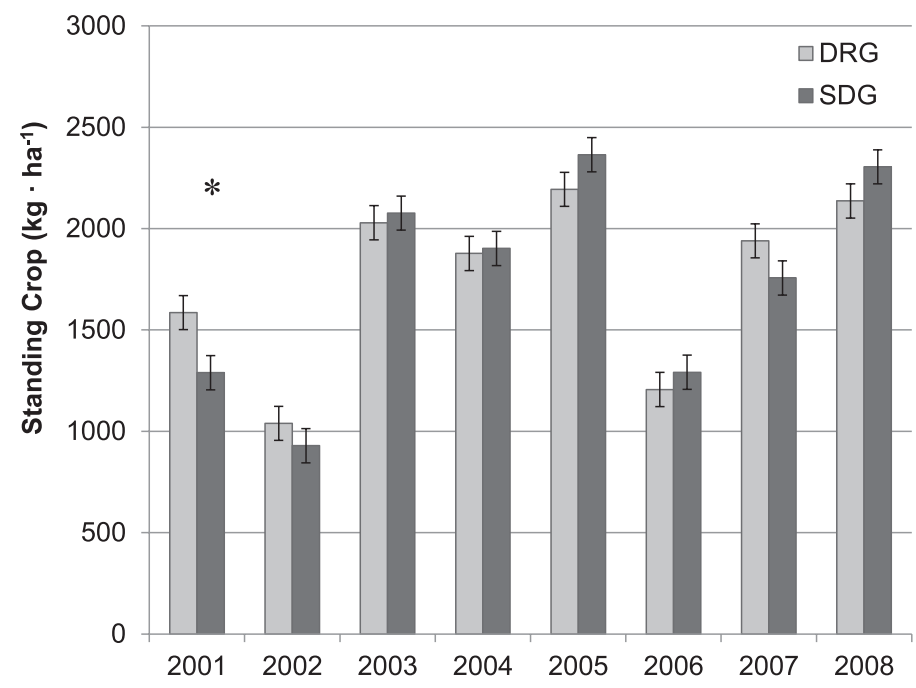

Figure 3. Grazing treatment-by-year interaction for total live standing crop (i.e., warm- and cool-season grasses, sedges, forbs, and shrubs) from 2001 to 2008 on eight-pasture short-duration grazing (SDG) and 4-pasture deferred-rotation grazing (DRG) pastures. ${ }^{*}$ Indicates significant differences between grazing treatments $(P<0.1)$.

\section{Livestock Performance}

There were no average daily gain $(P=0.15)$ differences of heifers grazed on SDG and DRG treatment pastures. Heifer daily gain averaged $0.84 \pm 0.05 \mathrm{~kg} \cdot \mathrm{d}^{-1} \mathrm{SE}$ over all treatments and years. Daily gain averaged over grazing treatments was greater $(P=0.06)$ in $2007\left(0.91 \pm 0.03 \mathrm{~kg} \cdot \mathrm{d}^{-1} \mathrm{SE}\right)$ than in $2006\left(0.80 \pm 0.03 \mathrm{~kg} \cdot \mathrm{d}^{-1} \mathrm{SE}\right)$ and $2008(0.79 \pm 0.03$ $\left.\mathrm{kg} \cdot \mathrm{d}^{-1} \mathrm{SE}\right)$.

\section{DISCUSSION}

\section{Change in Frequency of Occurrence}

Frequency of occurrence of native mid- and tall grasses increased or did not change on both SDG and DRG pastures over the $10 \mathrm{yr}$ of the study. Considering that the pastures were in good to excellent range condition at the beginning of the study, neither grazing method appeared to negatively affect range condition. Additionally, there was a decrease in frequency of occurrence of plant species (e.g., western ragweed) that typically thrive when the prevalence of dominant grass species is reduced (Vermeire and Gillen 2000; Reece et al. 2004) (Table 2).

Greater positive change in frequency of prairie sandreed at the pasture level and little bluestem on interdune topographic positions of DRG pastures after $10 \mathrm{yr}$ indicates that DRG may favor these species over SDG. However, greater positive change in frequency of little bluestem on south slopes of SDG pastures compared to DRG pastures after the first $5 \mathrm{yr}$ as well as a greater increase in needlegrasses on SDG pastures during this same time period suggests that response to grazing method may vary by plant species, topographic position, and year. Owensby et al. (1973) reported that basal cover of desirable warm-season grasses increased with DRG on tallgrass prairie when compared to season-long grazing during the growing season. In contrast, research conducted on the mixed prairie of Wyoming found only minimal differences in basal cover of desirable grasses among DRG, SDG, and continuously grazed pastures (Hart et al. 1988; Manley et al. 1997).

Greater increases in frequency of occurrence of prairie sandreed on DRG pastures compared to SDG pastures may 
A)

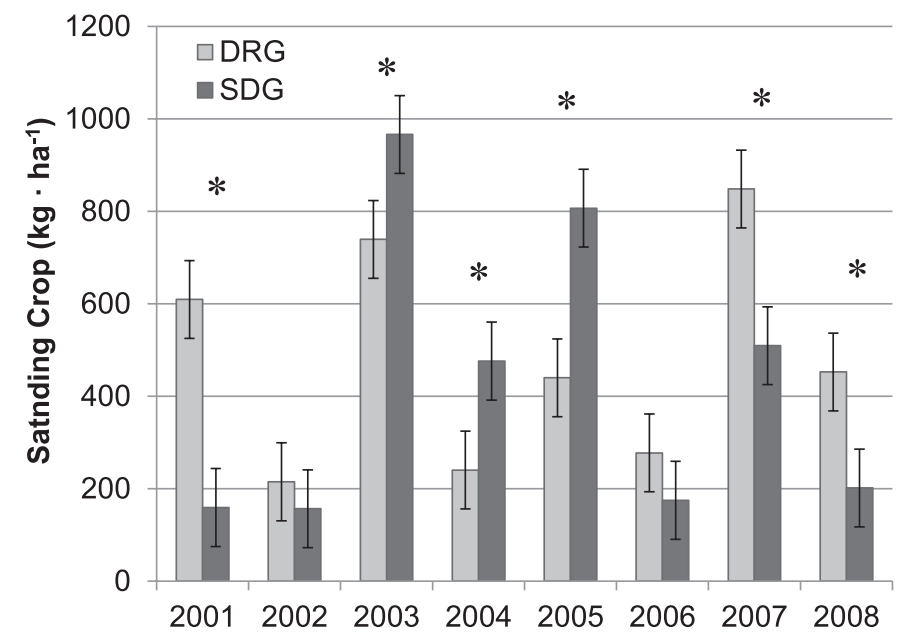

B)

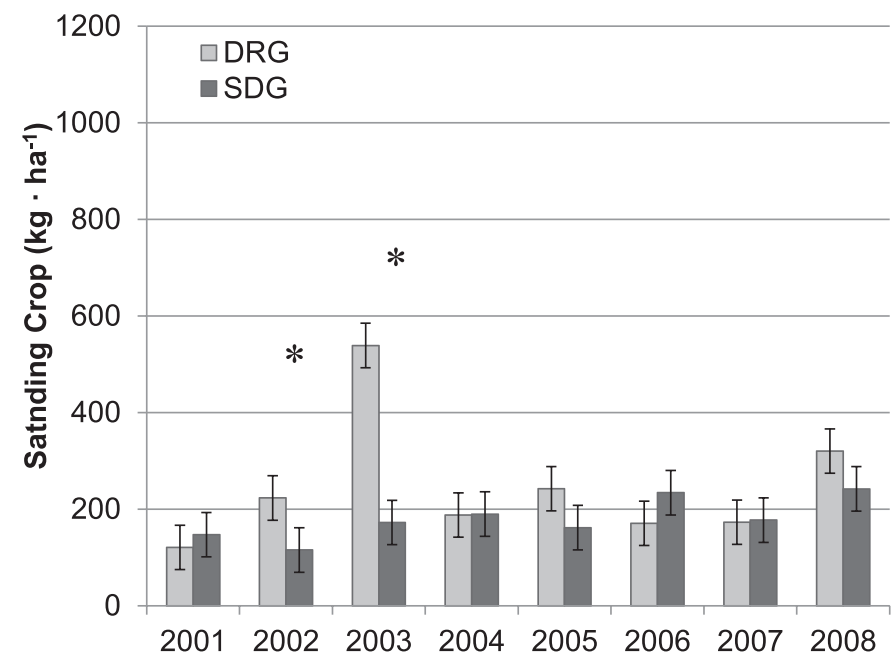

Figure 4. Grazing treatment-by-topographic position-by-year interaction for standing crop of $A$, forbs and $B$, sedges at interdune topographic positions from 2001 to 2008 on eight-pasture short-duration grazing (SDG) and four-pasture deferred-rotation grazing (DRG) pastures. *Indicates significant differences between grazing treatments $(P<0.1)$.

be the result of a number of timing-related factors including single vs. multiple grazing periods during the growing season and deferment of grazing in $1 \mathrm{yr}$ out of $4 \mathrm{yr}$ on DRG pastures. Research in the Sandhills has shown that grazing prairie sandreed in June or July for four consecutive years tends to reduce total organic reserves of individual plants (Reece et al. 1996). Because the grazing sequence of DRG pastures in our study changed annually, an individual pasture was grazed in June and/or July in only two of 4 years, whereas each of the SDG pastures were grazed once in June and July of every year. Reece et al. (1996) also reported that dividing seasonal stocking rates equally over multiple grazing periods during the growing season either reduced or had no effect on total organic reserves in prairie sandreed when compared to a single, full-use grazing period during the growing season. In hand-clipped plots, however, Mullahey et al. (1991) reported that a combination of multiple defolia-
A)

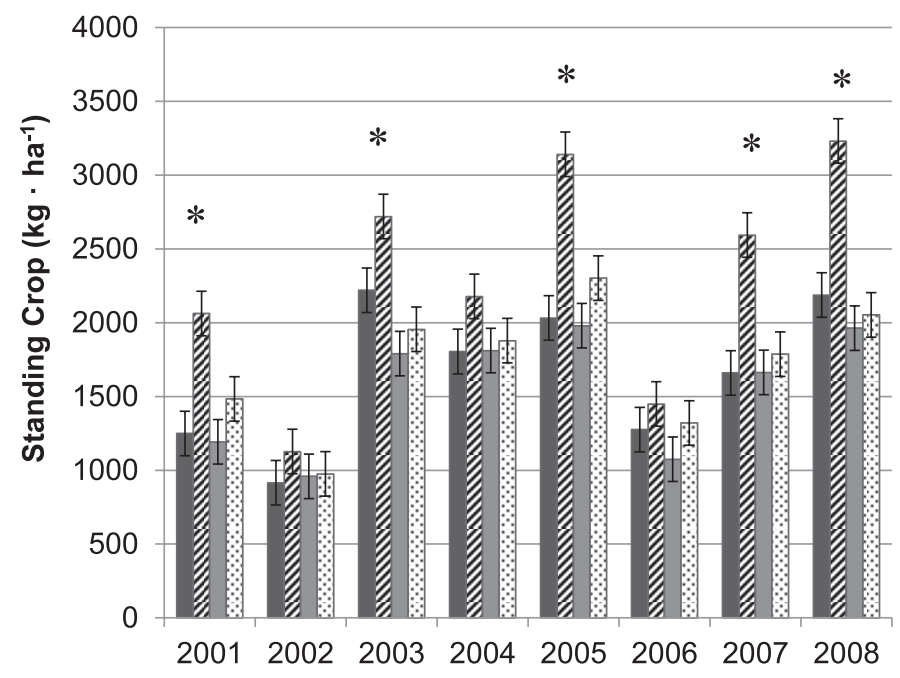

B)

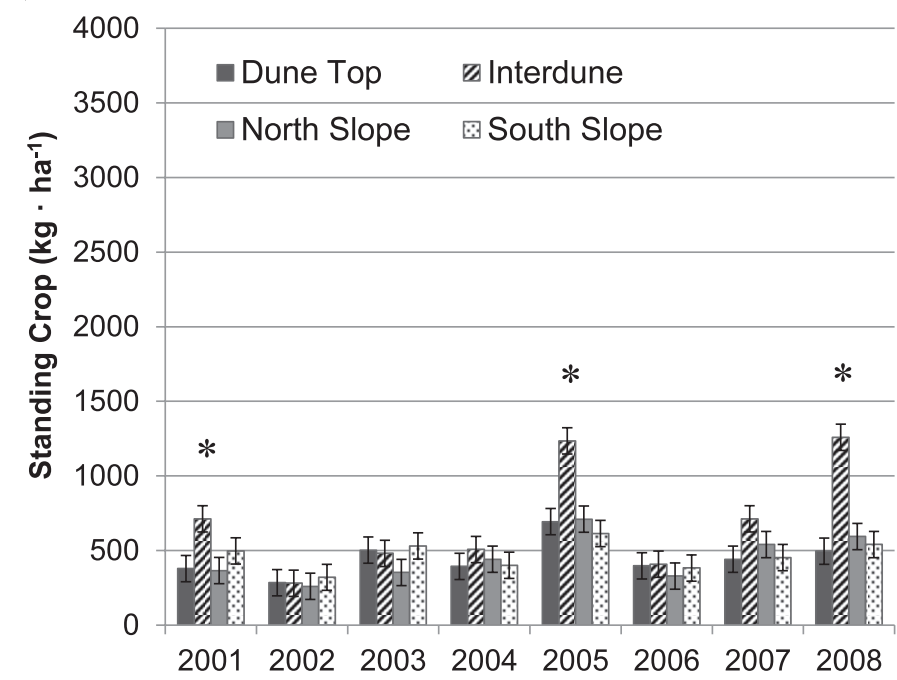

Figure 5. Topographic position-by-year interaction for standing crop of $A$, total live and B, cool-season grasses from 2001 to 2008 at four topographic positions. ${ }^{*}$ Indicates significant differences between interdune position and other topographic positions $(P<0.1)$.

tions from June to August increased annual dry matter yield after 3 yr, suggesting that multiple summer defoliations may benefit prairie sandreed.

Opportunities for numerous defoliations throughout the growing season may have detrimentally affected little bluestem plants on interdunes of SDG pastures after $10 \mathrm{yr}$. Little bluestem plants exposed to multiple defoliations during the growing season or a single heavy defoliation in August decrease in yield and morphological development when compared to only a single defoliation in June, July, or October (Mullahey et al. 1990). An increased number of grazing periods does not necessarily increase the number of defoliations on individual plants throughout the growing season (Derner et al. 1994), but little bluestem plants in heavily used areas such as interdunes may have had a greater likelihood of numerous defoliations on SDG pastures and, subsequently, reduced frequency of occurrence compared to the annually rotated, single grazing periods on DRG pastures. However, more research is needed to 
determine differences in cattle utilization based on topographic positions within the Sandhills.

In general, results of our study support the conclusions of others (Taylor et al. 1993; Reece et al. 1996) that increased number of grazing periods on semiarid rangeland does not increase the botanical composition of desirable, native warm-season grasses (i.e., promote secondary succession) any more effectively than a single grazing period with longer deferment at the same stocking rate. These results do not support our hypothesis that temporal changes in botanical composition of topographic positions favored by grazing cattle (i.e., interdunes) would be less pronounced in SDG pastures than in DRG pastures.

\section{Standing Crop}

Hart et al. (1988) and Manley et al. (1997) reported that herbage production did not differ between DRG and SDG at moderate and heavy stocking rates on mixed-grass prairie. Other research has generally shown that herbage production does not differ between SDG, other rotational grazing methods, and continuous grazing (Briske et al. 2011). Results of our study generally support these findings showing differences in total standing crop in only $1 \mathrm{yr}$ out of $8 \mathrm{yr}$ for total live standing crop and no grazing treatment or grazing treatmentby-topographic position differences for warm- and cool-season grasses, current year's growth of shrubs, or standing dead plant material. Similar to other research (Biondini et al. 1998; Gillen and Sims 2004; Heitschmidt et al. 2005; Patton et al. 2007), variability in annual herbage production was largely a result of other factors (e.g., topography and changes in annual and growing season precipitation) rather than grazing management practices at moderate stocking rates.

Greater amounts of sedge standing crop in 2002 and 2003 (Fig. 4B) on interdunes of DRG pastures may be the result of deferment to these pastures and single grazing periods during a dry year and in the following year, 2002 and 2003, respectively. Mature cows prefer level lowland areas to slopes and dune tops when grazing (Senft et al. 1985), and field observations indicated heavy utilization on interdune positions of SDG pastures during each of the three grazing cycles. Multiple grazing periods and the associated high grazing pressure on this topographic position during and following a dry year may have negatively affected sedge species on SDG pastures more than on DRG pastures.

Multiple opportunities for cattle to graze on the preferred interdune topographic position during the growing season also may have affected the increase in standing crop of forbs following a dry year from 2003 through 2005 (Fig. 4A) by decreasing competition from graminoid species more on interdunes of SDG pastures than DRG pastures following the drought in 2002. Research in the Sandhills has shown that multiple severe defoliations of perennial grasses may reduce productivity of warm-season grass species more than a single defoliation, and forbs in the Sandhills tend to increase in production when closely associated grass species are heavily defoliated (Reece et al. 1996; Reece et al. 2004). However, forb standing crop was variable between DRG and SDG pastures in other years.

\section{Livestock Performance}

Average daily gain of yearling heifers for both grazing treatments was similar to those observed for yearling steers grazing on comparable Sandhills range (Powell et al. 1982). Our results support research conducted on mixed-grass prairie in southeastern Wyoming (Hart et al. 1988; Manley et al. 1997) which reported no difference in weight gains of beef cattle between DRG (three herds and four pastures) and SDG (one herd and eight pastures). The lack of difference in daily weight gain between SDG and DRG in our study was likely a result of similar quality of available pasture forage between the grazing treatments. In a companion study, no differences were found in crude protein content or digestibility of diet samples collected from esophageally fistulated cows grazing within the DRG and SDG pastures in 2005 and 2006 (Schroeder 2007). Other studies also have shown that forage quality did not differ on pastures when SDG was compared to continuous grazing (Jung et al. 1985; Heitschmidt et al. 1987) or a less intensively managed Merrill four-pasture, three-herd grazing treatment (Taylor et al. 1980).

\section{MANAGEMENT IMPLICATIONS}

Multiple grazing periods associated with SDG are commonly reported anecdotally as a means to improve yearling cattle performance and vegetation response, but many experimental examinations of SDG compared to other rotational grazing methods and continuous grazing have not validated these reports (Briske et al. 2008). Results of our study also indicate that SDG was not a superior method of grazing when compared to the less intensively managed DRG in terms of improved livestock performance, positive changes in frequency of climax vegetation, and increased standing crop at different topographic positions on upland ecological sites in the Nebraska Sandhills. Single grazing periods associated with the DRG treatment also were less detrimental to certain plant species (i.e., prairie sandreed) and vegetation at specific topographic positions (i.e., interdunes). In pastures with variable topography, key management species on favored topographic positions such as Sandhills interdunes may have a greater likelihood of being overused when exposed to multiple-grazing-period methods such as SDG rather than a single-grazing-period method such as DRG. Overall, the lack of increased animal performance and vegetation productivity within the SDG pastures compared to DRG does not justify the likely increased cost and labor (i.e., increased fencing and water points, frequent livestock movement, etc.) associated with implementation of this grazing method.

\section{LITERATURE CITED}

Ash, A. J., J. P. Corfield, J. G. Mclvor, And T. S. KsIKSI. 2011. Grazing management in tropical savannas: utilization and rest strategies to manipulate rangeland condition. Rangeland Ecology \& Management 64:223-239.

Barnes, P. W., and A. T. Harrison. 1982. Species distribution and community organization in a Nebraska Sandhills mixed prairie as influenced by plant/soilwater relationships. Oecologia 52:192-201.

Barnes, P. W., A. T. Harrison, and S. P. HeinisCh. 1984. Vegetation patterns and relation to topography and edaphic variation in Nebraska Sandhills prairie. The Prairie Naturalist 16:145-158.

Barnhart, S., D. Morrical, J. Russell, K. Moore, P. Miller, and C. Brummer. 1998. Pasture management guide for livestock producers. Ames, IA, USA: University Extension, lowa State University. 104 p. 
Biondini, M. E., B. D. Patton, and P. E. Nyren. 1998. Grazing intensity and ecosystem processes in a northern mixed-grass prairie, USA. Ecological Applications 8:469-479.

Briske, D. D., J. D. Derner, J. R. Brown, S. D. Fuhlendorf, W. R. Teague, K. M. Havstad, R. L. GILLEN, A. J. Ash, AND W. D. WilLms. 2008. Rotational grazing on rangelands: reconciliation of perception and experimental evidence. Rangeland Ecology \& Management 61:3-17.

Briske, D. D., J. D. Derner, D. G. Mllchunas, and K. W. Tate. 2011. An evidenced-based assessment of prescribed grazing practices. In: D. D. Briske [ED.]. Conservation benefits of rangeland practices: assessment, recommendations, and knowledge gaps. Lawrence, KS, USA: Allen Press. p. 22-47.

Daubenmire, R. F. 1968. Plant communities: a textbook of plant synecology. New York, NY, USA: Harper and Row. 270 p.

Derner, J. D., R. L. Gillen, F. T. McCollum, and K. W. Tate. 1994. Little bluestem tiller defoliation patterns under continuous and rotational grazing. Journal of Range Management 47:220-225.

DeRneR, J. D., AND R. H. HaRt. 2007. Livestock and vegetation responses to rotational grazing in short-grass steppe. Western North American Naturalist 67:359-367.

GerRISH, J., AND C. RoBeRTs. 1999. Missouri grazing manual. Columbia, MO, USA: MU Extension, University of Missouri-Columbia. $172 \mathrm{p}$.

Gillen, R. L., AND P. L. Sims. 2004. Stocking rate, precipitation, and herbage production on sand sagebrush-grassland. Journal of Range Management $57: 148-152$

Hart, R. H., M. J. Samuel, P. S. Test, and M. A. Smith. 1988. Cattle, vegetation, and economic responses to grazing systems and grazing pressure. Journal of Range Management 41:282-286.

Heitschmidt, R. K., S. L. Dowhower, and J. W. Walker. 1987. Some effects of a rotational grazing treatment on quantity and quality of available forage and amount of ground litter. Journal of Range Management 40:318-321.

Heitschmidt, R. K., K. D. KLement, and M. R. Haferkamp. 2005. Interactive effects of drought and grazing on northern Great Plains rangelands. Rangeland Ecology \& Management 58:11-19.

HeITSCHMidT, R. K., AND J. WalKer. 1983. Short duration grazing and the Savory grazing method in perspective. Rangelands 5:147-150.

High Plains Regional Climate Center. 2012. Climate products. Available at http://www. hprcc.unl.edu/products. Accessed 8 October 2012.

Holechek, J. L., G. Hilton, F. Molinar, D. Galt, and R. Valdez. 2000. Short duration grazing: the facts in 1999. Rangelands 22(1):18-22.

Jung, H. G., R. W. RicE, And L. J. Koong. 1985. Comparison of heifer weight gains and forage quality for continuous and short-duration grazing systems. Journal of Range Management 38:144-148.

Kaul, R. B., D. M. Sutherland, and S. B. Rolfsmeier. 2006. The flora of Nebraska. Lincoln, NE, USA: School of Natural Resources, University of Nebraska-Lincoln. $996 \mathrm{p}$.

Manley, W. A., R. H. Hart, M. J. Samuel, M. A. Smith, J. W. Waggoner, JR., J. T. Manley. 1997. Vegetation, cattle, and economic responses to grazing strategies and pressures. Journal of Range Management 50:638-646.

McCollum, T. F., III, R. L. Gillen, B. R. Karges, and M. E. Hodges. 1999. Stocker cattle response to grazing management in tallgrass prairie. Journal of Range Management 52:120-126.

Milchunas, D. G., W. K. Lauenroth, P. L. Chapman, and M. K. Kazempour. 1989. Effects of grazing, topography, and precipitation on the structure of a semiarid grassland. Vegetatio 80:11-23.

Mueller-Dombois, D., AND H. Ellenberg. 1974. Aims and methods of vegetation ecology. New York, NY, USA: John Wiley and Sons. $547 \mathrm{p}$.

Mullahey, J. J., S. S. Waller, and L. E. Moser. 1990. Defoliation effects on production and morphological development of little bluestem. Journal of Range Management 43:497-500
Mullahey, J. J., S. S. Waller, and L. E. Moser. 1991. Defoliation effects on yield and bud and tiller numbers of two Sandhills grasses. Journal of Range Management 44:241-245.

Owensby, C. E., E. F. Smith, and K. L. Anderson. 1973. Deferred-rotation grazing with steers in the Kansas Flint Hills. Journal of Range Management 26:393-395.

Patton, B. D., X. Dong, P. E. Nyren, and A. Nyren. 2007. Effects of grazing intensity, precipitation, and temperature on forage production. Rangeland Ecology \& Management 60:656-665.

Powell, D. J., D. C. Clanton, AND J. T. Nichols. 1982. Effect of range condition on the diet and performance of steers grazing native Sandhills range in Nebraska. Journal of Range Management 35:96-99.

Reece, P. E., J. E. Brummer, R. K. Engel, B. K. Northup, and J. T. Nichols. 1996. Grazing date and frequency effects on prairie sandreed and sand bluestem. Journal of Range Management 40:112-116.

Reece, P. E., J. E. Brummer, B. K. Northup, A. E. Koehler, and L. E. Moser. 2004. Interactions among western ragweed and other Sandhills species after drought. Journal of Range Management 57:583-589.

Robel, R. J., J. N. Briggs, A. D. Dayton, and L. C. Hulbert. 1970. Relationships between visual obstruction measurements and weight of grassland vegetation. Journal of Range Management. 23:295-297.

Sampson, A. W. 1951. A symposium on rotation grazing in North America. Journal of Range Management 4:19-24.

Savory, A. 1983. The Savory grazing method or holistic resource management. Rangelands 5:155-159.

SAVORY, A. 1999. Holistic management: a new framework for decision making. 2nd ed. Washington, DC, USA: Island Press. $616 \mathrm{p}$.

Savory, A., And S. D. Parsons. 1980. The Savory grazing method. Rangelands 2:234237.

Schacht, W. H., J. D. Volesky, D. Bauer, A. J. Smart, and E. M. Mousel. 2000. Plant community patterns on the upland prairie in the eastern Nebraska Sandhills. The Prairie Naturalist 32:43-48.

Schroeder, P. R. 2007. Grazing system effects on cattle diet composition in the Nebraska Sandhills [thesis]. Lincoln, NE, USA: University of Nebraska-Lincoln. $84 \mathrm{p}$.

Scott, C. B., W. H. Schacht, and C. S. McCown. 1993. Response of herbaceous vegetation to short duration grazing in Central West Texas. Texas Journal of Agriculture and Natural Resources 6:1-9.

Senft, R. L., L. R. Rittenhouse, and R. G. Woodmansee. 1985. Factors influencing patterns of cattle grazing behavior on shortgrass steppe. Journal of Range Management 38:82-87.

Taylor, C. A., M. M. Kothman, L. B. Merrill, and D. Elledge. 1980. Diet selection by cattle under high-intensity low-frequency, short duration, and Merrill grazing systems. Journal of Range Management 33:428-434.

Taylor, C. S., T. D. Brooks, and N. E. Garza. 1993. Effects of short duration and highintensity, low-frequency grazing systems on forage production and composition. Journal of Range Management 46:118-121.

Tolstead, W. L. 1942. Vegetation of the northern part of Cherry County, Nebraska. Ecological Monograph 12:255-292.

Vermeire, L. T., And R. L. Gillen. 2000. Western ragweed effects on herbaceous standing crop in Great Plains grasslands. Journal of Range Management 53:335-341.

White, M. R., R. D. Pieper, G. B. Donart, and L. White Trifaro. 1991. Vegetational response to short-duration and continuous grazing in southcentral New Mexico. Journal of Range Management 44:399-403.

WiLlams, E. J. 1949. Experimental designs balanced for the estimation of residual effects of treatments. Australian Journal of Scientific Research 2:149-168. 